\title{
A origem animal de deus: Flávio de Carvalho e a figura do artista enquanto um etnógrafo da mente
}

\author{
The animal origin of god: Flávio de Carvalho and the artist as an \\ ethnographer of the mind
}

\author{
Augusto de Guimaraens Cavalcantia
}

\begin{abstract}
Resumo Este artigo tem por objetivo basilar problematizar a dimensão dialógica entre etnografia e arte na poética composicional de Flávio de Carvalho. Tendo como fio condutor o livro póstumo A origem animal de deus (1973), procuraremos investigar a instância etnográfica tal como a entendia Flávio e seu surrealismo particular; não apenas como uma prática circunscrita a um só gênero de escrita, mas também como uma forma de visão de mundo, um espaço teórico reinventor de tradições, um método de produção de conhecimento e um processo de crítica cultural.
\end{abstract}

Palavras-chave Crítica cultural; Surrealismo etnográfico; Antropologia da Literatura.

Abstract The main objective of this article is to problematize the dialogical dimension between ethnography and art in the work of Flávio de Carvalho. By focusing his posthumous book A origem animal de deus (1973), we will seek to investigate the ethnographic instance as it was understood by Carvalho's surrealism; not only as a practice circumscribed by a single writing genre, but also as a form of world perspective, a theoretical space of the reinvention of tradition, a method of knowledge production and cultural critique.

Keywords Cultural critique; Ethnographic surrealism; Literary Anthropology.

\section{INTRODUÇÃO}

Sem óculos, só posso ver com os olhos da alma - e os olhos da alma, eu tenho sempre voltados para o antropófago Flávio de Carvalho. (ANDRADE apud TOLEDO, 1994, p. 430)

a Augusto de Guimaraens Cavalcanti é doutor em Ciências Sociais pela PUC-Rio, tendo defendido a tese "Surrealismo no Brasil: A origem animal de deus, O púcaro búlgaro e Invenção de Orfeu: Flávio de Carvalho, Campos de Carvalho e Jorge de Lima" em 2015.2, com orientação de Maria Isabel Mendes de Almeida e coorientação de Paulo Henriques Britto. É poeta, ensaísta e romancista, tendo publicado, dentre outros: Fui à Bulgária procurar por Campos de Carvalho (2012, 7Letras) e Máquina de fazer mar (2016, 7Letras). 
Ao caracterizar a arte moderna e sua dimensão crítica, Giulio Argan (1995, p. 29) distinguiu dois vetores organizacionais pelos quais se ordenaram as produções artísticas do século XX: uma vertente construtivista e outra surrealista. ${ }^{1}$ Enquanto os construtivistas propor-se-iam adequar a sensibilidade artística ao ritmo do trabalho industrial, baseando sua produção numa irrestrita racionalidade da forma artística e, também, numa conciliação operativa da arte com a sociedade, a corrente surrealista, por sua vez, contrapor-se-ia ao mundo de produção massificada, ao afirmar a instância artística como meio potencial expressionista de impulsos mentais inconscientes.

Todavia, a antinomia entre construtivistas e surrealistas levantada por Argan não seria tão intransitiva ao ponto de não poder ser conjugada em certas circunstâncias: tal parece ser o caso de Flávio de Carvalho - artista cuja poética (o pensar que se faz de cada artista) indica mediar polos conflitantes e antagônicos, como, por exemplo, projeto e processo, ciência e devaneio. Nos livros flavianos Os ossos do mundo (1936) e, principalmente, em A origem animal de deus (1973), lirismo e raciocínio aludem se tornar parte de uma mesma potência - de amplitude tanto etnográfica/teórica quanto artística.

Engenheiro, arquiteto, maquetista, pintor, desenhista, aquarelista, retratista, cenógrafo, teatrólogo, ensaísta, artista performático, filósofo da vestimenta, psicólogo, cronista, teórico, crítico de arte, escultor, etnógrafo, pensador, Flávio de Carvalho mobilizava em sua produção artística uma transversalidade de atuações. Tal transversalidade de atuações pode ser observada também nos dados biográficos do $\operatorname{artista}^{2}$ e na pluralidade de focos temáticos de sua obra ${ }^{3}$.

1 Às teses racionalistas dos construtivistas se relacionam: o cubismo, a arquitetura racional, o desenho industrial, o movimento holandês De Stijl, a escola de Bauhaus de Weimar e as pesquisas cinéticas e visuais. À corrente surrealista se ligam: os dadaístas, os expressionistas e a pintura metafísica. À medida que na conjuntura surrealista, a arte permaneceria como a única atividade singular e liberadora numa cultura de massas, no caso construtivista, transformado em técnico projetista, o artista recusaria o mito da arte como ofício sagrado ou inspirado, renunciando à categoria do intelectual ilustrado e se utilizando da tecnologia industrial para produzir objetos de uso corrente, dotados de uma qualidade estética própria cujo caráter funcional seria definido em sua linearidade lógica desde a fase de seu projeto.

2 Nascido em Amparo da Barra Mansa (RJ), no dia 10 de agosto de 1899 e radicado em São Paulo, Flávio de Carvalho era sobrinho-neto do mártir Tiradentes e neto do Barão de Cajuru. Morou na Europa de 1911 a 1922, tendo estudado em Paris e se graduado em engenharia civil em Londres. Já em São Paulo, Flávio participou como pintor da Semana de 22, da qual foi também um dos organizadores. Ao longo da vida, Flávio de Carvalho foi membro dos: Instituto de Engenharia de São Paulo, Instituto dos Arquitetos do Brasil, Instituto de Psicotécnica de Praga, International Institute of Arts and Letters da Academia de Ciências de Nova Iorque, além de Cavalheiro da Ordem de St. Hubert. (Cf: Carvalho, 1973, p. 120-30; Carvalho, 2005, p. 137; Carvalho, 2010).

3 Como escritor de ficção teórica, Flávio de Carvalho publicou: Experiência 2 (1931), Os ossos do mundo (1936) e a obra póstuma A origem animal de deus (1973). Como teatrólogo, Flávio escreveu e dirigiu $O$ bailado do deus morto. Como pintor, produziu inúmeras obras, dentre: $A$ inferioridade de deus (1931), Série trágica (1947) e Estudo para Nossa Senhora da Noite (1954). 
Não por acaso, Flávio foi referido como "revolucionário romântico - a genialidade em estado selvagem" (Corbusier apud Toledo, 1994, p. 76) por Le Corbusieur e como "o Leonardo da Vinci brasileiro" por Jean Lurçat (apud TolEdo, 1994, p. 431). Por sua vez, em ocasião de sua morte, Assis Chateaubriand o descreveu como "pintor maldito [...] hirsuto fauno [...] Antiestoicista passivo, antiracionalista, antitépido, antiespiritualista, amoral - olimpicamente amoral - jaguar de pelo eriçado, com regras própria de viver [...] subversivo em estado de revolução permanente" (Chateaubriand apud Toledo, 1994, p. 400-401).

De forma análoga a tal pluralidade de atuações, sua persona operava com paradoxos: ao mesmo tempo em que era um técnico projetista e um engenheiro de formação tradicional, Flávio atuava simultaneamente como um arquiteto vanguardista lançando projetos como manifestos subversivos em concursos públicos ${ }^{4} \mathrm{e} u m$ expressionista sondando e divulgando a arte moderna, sobretudo, a surrealista. Em seus pensamentos inovadores se combinavam, sem nenhuma síntese facilitadora ou compartimentalização estanque, afã construtivista e filosofia surrealista - de um surrealismo revisitado e revitalizado.

Tendo isso em vista, ao prefaciar o livro Os ossos do mundo, Gilberto Freyre sublinhou que, em F.C. a objetividade de arquiteto-engenheiro se associava a certo lirismo expressionista ${ }^{5}$. Por conseguir combinar, de forma particularíssima, um senso objetivo de técnico moderno com traços líricos de sensibilidade extensa é que a poética flaviana deveria ser narrada como um lirismo novo - pós-modernista em tempos modernistas:

Como retratista, pintou, dentre outros, Elsie Houston (1933), Mário de Andrade (1939) e Murilo Mendes (1951). Como escritor periódico, publicou "Notas para a reconstrução de um mundo perdido" em coluna de O Diário de São Paulo (1957-58) - artigos posteriormente apresentados em tese no simpósio "O Homem e a Civilização" (1962), na University of California. Como crítico de arte, escreveu, dentre outros: "A escultura culinária” (1935), "Manifesto do III Salão de Maio" (1939) e "Quatro períodos de Tarsila" (1940). Como filósofo da vestimenta, elaborou a tese "A moda e o novo homem" em O Diário de São Paulo (1956), além de compor os trajes "New look" com passeatas pelas ruas paulistanas. Dentre os textos de Flávio como teórico da arquitetura, está a tese/manifesto "A cidade do homem nu" (1930). Como projetista três de seus projetos foram realizados: "Conjunto de Casas da Alameda Lorena" (1936/1938), "Fazenda Capuava" (1939) e "Monumento a Garcia Lorca na Praça das Guianas, SP" (1968). Dentre seus principais projetos não realizados, estão: "Farol de Colombo" (1928), Monumento ao prisioneiro político desconhecido" (1954) e "Universidade Internacional de Música de Guaratinguetá" (1955).

4 Em seu primeiro projeto público como arquiteto, em 1926, Flávio de Carvalho cunhou o pseudônimo "Eficácia”. Tal termo viria a ser reutilizado em 1927 (em projeto para a UFMG) e em 1928 (no concurso da Embaixada da Argentina - RJ). Ainda no campo de atuação da arquitetura, Flávio provocativamente apresentou em 1939 um projeto sob o pseudônimo de "Paraquedas".

5 Aqui, é importante ressaltar que o prefácio de Os ossos do mundo foi escrito por Gilberto Freyre, numa época em que os cientistas sociais comumente escreviam crítica literária. No contexto moderno brasileiro, a continuidade entre literatura e ciências sociais possuía certa indistinção profícua de um campo intelectual pelo qual os cientistas procuravam no âmbito da literatura o conhecimento de uma realidade capaz de ampliar o debate da cultura. 
Flávio de Carvalho é dos que pela idade e pelas circunstâncias poderia ter sido 'modernista' em 23. Modernista como qualquer dos dois Andrade, o moreno e o louro. Mas não foi. Sua geração intelectual é outra. Ele é pós-modernista legítimo: apareceu depois do 'modernismo' e com outra mensagem. Intensamente moderno, mas despreocupado do 'modernismo' literário em que aqueles dois escritores admiráveis se extremaram até quase o ridículo. [...] Flávio de Carvalho arregala olhos de menino e às vezes de doido para ver o mundo. Por isso vê tanta coisa que o adulto todo sofisticado não vê. Vê tantas relações entre as coisas que os adultos cem por cento e os completamente normais deixam de ver. Do sentido dessas relações vem o lirismo novo e profundo, cheio de grandes coragens, que há nas notas de viajante de Flávio de Carvalho. [...]. Há no autor deste livro [Os ossos do mundo] uma grande sensibilidade ao lado do gosto de ser objetivo. Um grande lirismo, ao lado do senso científico. A capacidade de abstração e de análise ao lado de uma poderosa sensualidade de expressão. Não que ele seja um verbalista, muito menos o que os franceses chamam com desprezo um tropicalista. Ao contrário: é sóbrio e preciso. Mas há cor e sexo nas suas palavras às vezes meio soltas, sem nenhum controle rígido, nem da gramática, nem da pontuação convencional, nem mesmo do que um crítico nosso conhecido chama ‘dignidade de linguagem’. (Freyre in: Carvalho, 2005, p. 8-9).

Por sua vez, como observou certa vez Carlos Drummond de Andrade, a totalidade da produção flaviana lidaria inevitavelmente com a abrangência do mito: "Tudo em seu trabalho é rigorosamente calculado, não de acordo com os princípios acidentais de um estilo ou de um sistema, porém de acordo com os princípios que vigoram desde que o mundo é mundo" (ANDrAde apud Leite, 2008, p. 32).

Produto do raciocínio e da imaginação, os experimentos de Flávio com o pensamento e com a linguagem presentes em A origem animal de deus suscitam investigar o desconhecido como faria um etnógrafo da mente - inventor de uma "psicoetnografia" própria (CARvalho apud Antelo, 2010, p. 190). Sobre tal psicoetnografia imaginada por Flávio, alude ser elucidativa a epígrafe presente em $O s$ ossos do mundo (1936) - no capítulo "O mapa da saudade, o primeiro mapa do mundo" - escrita pelo astrofísico Eddington: "Da natureza intrínseca...a ciência nada sabe...tanto quanto sabemos a matéria pode até mesmo ser mental" (EDDINGTON apud CARvalHo, 2005, p. 59).

Em prol de uma prática etnográfica ampliada ao inconsciente, Flávio de Carvalho pode ser lido como um investigador de forças anímicas e um pesquisador das sugestibilidades que tende a não considerar a verdade científica como uma 
condição lógica cativa de sistemas raciocináveis. Uma concepção raciocinada a priori por uma lógica dialética (clausurável a uma só localização) não seria suficiente para abranger o caráter múltiplo do rigor artístico de sua escrita teórica. Presente principalmente em $A$ origem animal de deus, o processo criativo de viés etnográfico da ensaística flaviana suscita a investigação das complexidades e paradoxos humanos. Como propõe Flávio: “A verdade não é uma condição lógica nem raciocinada ou raciocinável, é muito mais profunda que a dialética regional de uma lógica" (CARvalHo, 2005, p. 44).

Para o artista-cientista-escritor Flávio de Carvalho, o etnógrafo - "homem que coleciona e classifica sua alegria" (CARVALHO, 2010, p. 56) - manteria no mundo permanentemente presente uma atmosfera de sonho, como se, por meio de uma prática etnográfica particularíssima, o sujeito de escrita entrevisse um momento de consciência anterior ao processo de individuação e retornasse à pré-história do indivíduo para buscar na linguagem um estado bruto, poético e incandescente capaz de fornecer novas formas e sentidos a potencialidades de pré-individuação.

Segundo leitura de F.C., tanto o etnógrafo quanto o arqueólogo deveriam participar auspiciosamente da sugestibilidade do mundo. Pela acumulação residual de objetos de incitação anímica, o arqueólogo e o etnógrafo deveriam ser capazes de encontrar nos resíduos estudados fontes de incitação poética. Seguindo tal perspectiva, o processo de percepção arqueológica e etnográfica deveria se aproximar da compreensão processual artística, no sentido de estar investido de uma predileção pela imprevisibilidade das descobertas:

O arqueólogo bem-comportado se parece um tanto com o psicólogo bem-comportado. Mecanizados por um catecismo científico, eles têm medo do mundo e do pecado e só enxergam a linha traçada pelo catecismo - são equilibristas que pisam resolutamente sobre um fio suspenso no escuro e poucas vezes se lembram que psicologia e arqueologia não são atos de equilíbrio, mas sim coisas que surgem da grande sugestibilidade do mundo, coisas catastróficas que se sentem e cuja emoção e sensibilidade são exclusivamente ampliadas pelo raciocínio. Uma introspecção arqueológica privada de sentimento, isto é, da força penetrante da elaboração poética, nunca pode ressoar à plástica do resíduo e restabelecer o tumulto anímico colocado pelo homem na época examinada, mesmo porque o Homem que criou o resíduo não era arqueólogo. Para desvendar os acontecimentos representados por um resíduo é necessário sentir a força psicológica acumulada e emanada do resíduo, e com o auxílio do raciocínio compreender a emoção sentida. O arqueólogo tem de penetrar nas sucessivas fases que plas- 
maram o resíduo, tem de ser intensamente humano e sentir o palpitar da alma do homem e da civilização que confeccionou o resíduo; além de humano e de sentir todas as emoções do artista e da civilização que construiu e fez, ele tem também de ser psicólogo, isto é, compreender os motivos dessa construção e dessas formas. [...] O arqueólogo malcomportado tem muito mais probabilidades de compreender o não tempo, de viver igualmente à vontade em todas as épocas que examina, desabrochando todas as camadas, mesmo as mais profundas da sua sensibilidade, e que estão naturalmente alheias e bem afastadas do catecismo científico do seu mundo. A noção de tempo como a compreendemos parece nada significar numa sensibilíssima introspecção arqueológica, e o poder de sentir o passado e a espécie parece indicar a capacidade que tem o homem de viver fora do tempo. (CARVAlHo, 1936, p. 88-91; grifos colocados).

Tendo em vista que, em linhas gerais, a própria ideia de etnografia é amplamente debatida na antropologia, nos utilizaremos de uma noção de escrita etnográfica análoga à compreendida por Roy Wagner - em A invenção da cultura (1975) - e correlata à leitura de James Clifford (1998) que compreende a etnografia como uma forma de crítica cultural em estado de potência. Por expandir o sentido pelo qual escrever e saber se interconectam em um mesmo processo de combinação teórico-prática, Clifford questiona uma ciência que, por método, separa assepticamente sujeito e objeto, teoria e prática. ${ }^{6}$

Por sua vez, como propõe Roy Wagner, todo esforço potencialmente etnográfico em conhecer outra cultura deve começar por um ato de invenção, uma vez que é "impossível objetificar, inventar algo sem 'contrainventar' seu oposto" (WAGNER, 2012, p. 128). Sendo o homem "o xamã de seus significados" (WAGNER, 2012, p. 97), a linguagem e a cultura estão sempre em processo de serem inventadas e contrainventadas numa dialética singular.7 Sendo toda realidade composta por interpretações circunstanciadas e atualizadas pelos símbolos, em linhas gerais,

6 Ao compreender a etnografia como uma forma potencial de crítica cultural, James Clifford (1998) inclui a dimensão ficcional da escrita e da experimentação textual na base antropológica da produção de narrativas. Ao assumir uma posição distanciada em relação ao contexto modernista, em sua pesquisa Clifford transforma os antropólogos modernos em nativos que transitam pelas fronteiras móveis entre literatura e antropologia. Mostra, assim, como a antropologia moderna contribuiu para uma crescente visibilidade dos processos criativos - e, num sentido mais amplo, poéticos - pelos quais objetos culturais são inventados ao longo do tempo.

7 Como meio de alternativa metodológica, Roy Wagner (2012) propõe uma concepção de dialética mais próxima do modelo grego original: a de uma tensão ou alternância, ao modo dialógico, entre duas concepções ou pontos de vista simultaneamente contraditórios e interdependentes entre si. Para Wagner, por meio de tal conceituação dialética passaria a ser possível pensar numa antropologia que invente culturas ao invés de uma cultura unívoca, coletivamente formulada mediante a aplicação universal de conceitos como intermediação e explicação. 
os significados humanos se baseiam nas relações que alinham; a linguagem e os significados inventam e reinventam o real.

Por tal perspectiva, alinhada à discussão antropológica contemporânea e ulterior à publicação de A origem animal de deus (1973), a prática etnográfica pode ser lida como um jogo de invenções pelo qual, em tensão dialética, textos da cultura se enredam no mundo em experimentos de mútua investigação entre etnógrafos e etnografados. Ao assumir toda lógica humana como antropológica em potencial - inventora de cultura -, todos os homens podem ser concebidos como "pesquisadores de campo que controlam o choque cultural da experiência cotidiana mediante todo tipo de regras, tradições e fatos imaginados ou construídos" (WAGNER, 2012, p. 75).

Assim, pretendemos neste ensaio problematizar a face etnográfica de Flávio de Carvalho, presente, sobretudo, no livro póstumo A origem animal de deus. Tendo como hipótese a figura do artista como um etnógrafo da mente (ou psicoetnógrafo) em contato com uma "onirografia" (CLIFFORD, 1988, p. 165) do inconsciente primitivo da espécie, abordaremos certas práticas teóricas interdisciplinares presentes na escrita de Flávio, tendo como ponto de partida a concepção flaviana de uma "etnografia da história8".

Substantivada enquanto manifestação crítica de uma concepção unidimensional do real, a etnografia é entendida pela escrita flaviana como, mais do que um estilo literário, um método de aproximação e de investigação da realidade. Justamente por dialogar com mitos na formulação em si das realidades que Flávio recupera em $A$ origem animal de deus é que é possível pensar numa formulação mítico-poética do elemento primitivo em sua escrita enquanto indício do humano em si mesmo.

Entendida como questão filosófica por Flávio de Carvalho, a pesquisa etnográfica alude ser transvalorada em $A$ origem animal de deus através da nomeação do primitivo como reminiscência de um inconsciente ancestral anímico. Por tomar a mente enquanto um elemento da cultura, Flávio alude à busca de um dinamismo mental primitivo de energia inventiva através de investigações ensaísticas sobre povos ancestrais. Suas investigações de viés etnográfico dos resíduos ancestrais dos ossos do mundo remetem à arte primitiva como manifestação do inconsciente ancestral e, por isso, comum da espécie:

8 "A etnografia da história atuando magicamente pela repetição prolongada, hipnotiza o homem no seu roteiro inevitável" (CARVALHO, 2010, p. 17; grifos colocados). 
O acontecimento remoto é mais visível e apreciável ao observador que os acontecimentos que o afogam. [...]. Um exame dos objetos do mundo e das coisas encontradas no correr da vida, não somente desperta uma nova sensibilidade no indivíduo, e que antes se achava adormecida, mas também estabelece uma ligação anímica maior entre o indivíduo e o objeto examinado; o objeto adquire para o indivíduo um valor e uma sugestibilidade que ele dantes não possuía; o objeto torna-se uma fonte de recordação das dúvidas e do drama da vida... o objeto vive tanto quanto o próprio indivíduo. De uma coisa jogada no acaso do mundo, ele se transforma numa coisa transbordando de sugestibilidade, ele adquire 'atmosfera'. Semelhantes sensações não são mensuráveis pela física moderna, que fracassa completamente, quando a noção de tempo perde o seu sentido vulgar de cronômetro. A atmosfera de um objeto são as "recordações" que o objeto oferece ao observador; estabelece-se uma ligação entre as camadas profundas do inconsciente; essas camadas profundas ressoam ao aspecto do objeto do observador, e o aspecto do objeto surge na tona do consciente, não propriamente uma imagem, mas a sugestibilidade de uma recordação longínqua. [...]. Todo o mundo objetivo e em particular os ossos do mundo, os resíduos ancestrais, funcionam como condutores de verdade em consequentemente, oferecem um poder terapêutico pouco compreendido hoje devido ao infeliz e tacanho espírito científico do século. [...]. O autor acredita que a história da espécie está intimamente ligada ao que é encontrado pela psicanálise nas profundezas do inconsciente e que os próprios resíduos deixados pelo homem nas lendas, nas cerimônias, e apanhados pela arqueologia, pela etnologia, mostram não somente que o conteúdo do indivíduo é uma repetição da história da espécie, mas também que existe uma perfeita identificação entre este conteúdo e o que aconteceu na vida da espécie. (CARVALHO, 2005, p. 41-98).

De forma ampla, ampliada às camadas mais profundas da mente humana, a arte indica ter, segundo leitura presente na escrita de Flávio de Carvalho, um sentido tão sugestivo quanto orientador na história da humanidade. Por isso, sua teoria da arte é, ao mesmo tempo, uma teoria da cultura. Para Flávio, a arte incita ser lida como um ser vivo através de um amplo gráfico demonstrativo dos anseios de grupos humanos ao longo da história.

Ao perscrutar o desenvolvimento da arte ao longo do tempo, Flávio de Carvalho estabelece em sua análise um ciclo revolucionário com etapas características das grandes emoções do homem. Em sua investigação teórica, a história da arte moderna é dividida em quatro períodos: impressionismo, abstracionismo, 
expressionismo e surrealismo. Tal ciclo seria impreterível de ser confrontado por qualquer interpretação que averiguasse a arte moderna para além dos diagnósticos puramente estéticos. Tanto para os surrealistas, como para Flávio, a arte não seria um mero brinquedo estético da civilização moderna, mas sim um embrião da gênese humana do pensamento:

A arte é sempre em algum modo a síntese das grandes aspirações dos povos e das necessidades da história, é um gráfico da história como ser vivo [...] A arte que interessa é aquela que procura destruir uma suposta verdade, é uma força desorganizadora que oferece o encanto do desconhecido, que procura destruir o dogma organizado, e mostra uma coisa sugestiva capaz de orientar o homem numa outra teoria. É uma mostra de juventude, de combate ao tédio - nasce da revolta como exemplar de gênio e o seu fatalismo está no inevitável conceito de desorganizar o organizado. O organizado, uma vez estabelecido, torna-se por necessidade de contraste uma entidade instável própria a ser desmantelada, sugestiva a ponto de provocar o golpe de gênio que a destruirá. O conceito de arte é esse golpe de gênio destruidor. Ele vem como um castigo do dogma organizado e consegue manter a sua pureza genial, o seu encantamento por pouco tempo. É logo castigado com o enfeite da incompreensão. (CARVALHO, 2015, p. 73-125).

Por via de uma produção capaz de transcender os dogmas da forma e os paradigmas realistas de descrição mimética do objeto representado, o surrealismo é referido por F.C. como uma arqueologia do inconsciente e uma psicoetnografia (etnografia da mente) - potencializador de um tipo de produção artística onde sensibilidade e pensamento se correspondessem em potência ${ }^{9}$.

Como ressalta Raúl Antelo (2010, p. 192), para a visão de mundo de F.C. e seu sequente arcabouço analítico, o problema estético não deve estar restrito às definições estáveis do modernismo e de seus impasses lógicos. Antes, menciona ser produzida por uma transversalidade de saberes capaz de atravessar a consistência "linguageira" do homem através de uma ciência ainda por vir - a que Flávio chama na falta de rótulo melhor, de psicoetnografia. Tal ciência futura deveria ser capaz de reunir arqueologia, psicologia, poesia e etnografia numa área de conhecimento

9 Tal leitura de Flávio de Carvalho sobre o surrealismo está presente em "O aspecto psicológico e mórbido da arte moderna", tese ensaística apresentada no "Segundo congresso internacional de estética e de ciência da arte" (1937), que defendia que a arte moderna teria conhecido, com o anarquismo dadá, uma fase final de exposição de suas chagas. Esgotada tal fase, as feridas da arte moderna deveriam ser "tratadas" por uma arqueologia do inconsciente a ser produzida pelos surrealistas. (Cf: CARvalHo, 2010, p. 61-62). 
em que anacronismo e modernidade não fossem considerados incompatíveis e diametralmente opostos.

Paralela a tal busca ambicionada de uma psicoetnografia da humanidade através da história, em $A$ origem animal de deus, o elemento humano é buscado em suas manifestações físicas, mentais, arqueológicas, filosóficas e etnográficas ${ }^{10}$. Análoga a tal abrangência de busca, a instância etnográfica é apontada como uma prática errante pela qual o etnógrafo e o observador nômade dialogam num plano análogo de correspondência perspectivista e antissedentária pelo qual o artista procura um dinamismo mental primitivo de energia inventivo-poética.

Tendo isso em vista, a esfera ciência pode ser lida na escrita teórica de F.C. como uma instância plástica e compósita, cuja abrangência de apreensão indica se aproximar de uma percepção processual artística cuja prática, ao mesmo tempo planejada e intuitiva, busca adquirir perspectiva, ponto de vista e contraste. Não obstante, para Flávio, além de indispensável para qualquer observação mais atenta do real, por ter como base a ideia do deslocamento, o contraste conteria uma gravitação vital da mente do observador: "Contraste é vida. A própria existência das coisas só é observada via contraste" (CARvalho, 2010, p. 62); "quem viaja e deseja observar, não deve permanecer muito tempo no mesmo local, pois arrisca a se ambientar; e o observador ambientado é um mau observador: não enxerga porque é incapaz de fornecer contraste" (CARvalHo, 2005, p. 86).

Na prática etnográfica proposta por Flávio de Carvalho, em $A$ origem animal de deus, mais parece interessar a parte que pertence ao cientista descondicionado dos claustros tradicionais dos sistemas canônicos de pensamento ocidental. Seguindo perspectiva de Flávio, por não ser um monopólio oficial de determinadas ciências, o processo de compreensão científica deveria manter um diálogo suficientemente denso para, em interação com uma visão de mundo coadunada com a arte, ser capaz de abarcar as densidades psíquicas e culturais dos pensamentos humanos.

Ao se utilizar de materiais lendários como fontes de suas descobertas, a escrita de $A$ origem animal de deus pode ser aproximada de uma cosmovisão etnográfica (de traços e traçados surrealistas) realizada por Michel Leiris em África fantasma

10 De modo a exercer tal escopo perspectivista, para Flávio de Carvalho, o etnógrafo precisaria, além de viver a sensibilidade do período averiguado, ser um pouco arqueólogo, antropólogo e psicólogo dos resíduos mentais da época estudada em prospecção. Embora tenha em The golden bough: a study in magic and religion (1890) de Sir James Frazer uma fonte imprescindível de diálogo - reconhecendo a importância e a abrangência das análises frazerianas sobre a sequência transformativa do pensamento mágico, religioso e científico das sociedades primitivas até as contemporâneas -, a obra flaviana A origem animal de deus indica criar uma etnografia própria que chega até a criticar, em determinados momentos, certas leituras de Frazer que tendem ao naturalismo. 
(1934) e titulada por James Clifford (1988) de onirografia. O surrealismo é, para Clifford (1998), o cúmplice secreto da etnografia no século XX, tendo a prática surrealista reiteradamente profanado as fronteiras que separavam a arte da ciência no mundo moderno. ${ }^{11}$

Entendido como uma poética de apreensão do real e um método de exploração do desconhecido, o viés etnográfico do surrealismo propõe outra lógica que não a aristotélica helênico-ocidental ${ }^{12}$. Por sua vez, esboçada em termos de uma "poesia vivida e um desnortear-se" (LEIRIs, 2007, p. 19), a escrita etnográfica surrealista de Leiris, além de considerar os mitos como criações próximas dos sonhos, tende a considerar a viagem (tanto mental quanto de deslocamento geográfico) como meio potencializador de uma aventura poética com a linguagem - "um modo simbólico de interromper a velhice ao percorrer o espaço para negar o tempo" (LEIRIS, 2007, p. 53).

Através de uma estranha e particularíssima etnografia do inconsciente, na escrita de África fantasma, as noções de distanciamento, exotismo e representação do outro são retrabalhadas e reajustadas em função de critérios não mais geográficos ou culturais, mas de natureza metodológica proveniente da poética composicional de sua escrita - o pensar-fazendo do artista. Tal etnografia onirográfica seria responsável por provocar uma supressão de fronteiras entre os gêneros literários, tornando-se inclassificável enquanto poesia, narrativa em prosa, ensaio, crônica ou etnografia clássica. Transitando entre a poesia e a etnografia, Leiris acabaria por suprimir em sua produção as distinções entre o material "literário" e o "não-literário"13".

11 Ao focalizar as ligações entre o surrealismo e a etnografia na primeira metade do século XX (numa conjuntura crítica em que a etnografia era ainda uma prática incomum para os moldes tradicionais das ciências sociais e o surrealismo não era ainda uma província bem definida da arte e da literatura modernas), James Clifford observa entre ambas uma orientação comum em relação à ordem cultural de fragmentação e justaposição de valores: "A principal tarefa [de Marcel Mauss] era descobrir, em sua famosa frase, as várias 'luas mortas' no 'firmamento da razão'. Não há melhor sumário da tarefa do surrealismo etnográfico, uma vez que a 'razão' referida não é a paroquial racionalidade ocidental, mas o pleno potencial humano de expressão cultural" (ClifFORD, 1998, p. 146).

12 Como não são unidades estáveis, surrealismo e etnografia podem ser reinterpretados de acordo com o questionamento de uma série de distinções e unidades comuns entre arte e ciência. Como ressalta James Clifford, assim como o surrealismo não pertence exclusivamente ao campo da literatura, a etnografia também não é exclusiva à antropologia, uma vez que, em sua atividade textual híbrida, atravessa gêneros e disciplinas de forma multíplice. Tendo isso em vista, Clifford propõe ler o surrealismo etnograficamente através de um constructo capaz de pensar um tipo de conhecimento poético da realidade cuja implícita crítica cultural buscasse profundamente abalar as ordens inabaláveis de qualquer racionalismo filial.

13 Como aborda James Clifford (1988), ao questionar certas distinções científicas fundamentais entre práticas "subjetivas" e "objetivas", em África fantasma (1934), Michel Leiris realiza em sua escrita uma espécie de etnografia rigorosa e poética, centrada não no outro, mas no self e em seu peculiar sistema de símbolos. Em sua aventura mais mental do que física se reúnem 
De forma paralela, assim como em África fantasma, em A origem animal de deus, o componente primitivo não parece representar uma categoria étnica e nem, tampouco, somente um valor de choque frente a valores racionalistas modernos. Através de experimentos e investigações intermitentes com o real, ao longo do livro, a dinâmica psicoetnográfica de seu texto indica produzir uma ligação epistêmica com a realidade que toma a mente enquanto um elemento da cultura.

Tendo isso em vista, de modo análogo a certa indeterminação estilística de fronteiras classificatórias presentes na escrita de Michel Leiris que, incitada pela dimensão etnográfica do surrealismo, embaralhava as ordens classificatórias tradicionais em matéria de estilo, os escritos de $A$ origem animal de deus podem ser lidos como literatura, etnografia, filosofia, arqueologia mental e crítica artística.

Por trazer em sua escrita a busca de um inconsciente ancestral de onde deveria provir a vivacidade da arte moderna, para Flávio de Carvalho, a arte representaria o começo da civilização; o homem primitivo já nasceria artístico. Inventores da linguagem; seriam os poetas ${ }^{14}$ responsáveis por criar a memória da espécie, retirando o homem de sua primeira amnésia. Os homens primitivos repetiriam o que os poetas fabularam uma primeira vez, perpetuando, assim, a memória ancestral do mundo.

Mais indutivos do que dedutivos, os textos flavianos de viés etnográfico que compõem Os ossos do mundo e, sobretudo, A origem animal de deus, sugerem não explicações conceituais ou justificativas de uma produção paralela, mas, antes, fragmentos de um mesmo conjunto de criação - tendo, tanto amplitude teórica, quanto artística. Precisamente por conter traços paradoxalmente filosóficos não condizentes com os livros de viagens habituais (baseados em observações realistas e trivializáveis sobre monumentos e hábitos correntes dos povos visitados), a obra flaviana mais etnográfica - A origem animal de deus - pode ser aludida como uma invenção ficcional-crítica de abrangência poética; obra ensaística cujo experimento de livro é gerado a partir de uma espécie de etnografia experimental que

elementos de uma escrita formada por flashes relativos a fatos subjetivos, bem como coisas exteriores (vividas, observadas ou aprendidas), vistas sob um ângulo meio documental, meio poético.

14 Aqui, é importante ressaltar que cada sociedade tem sua definição de poeta, já que este é um ethos em permanente ressignificação. Mircea Elíade (2002, p. 44), por exemplo, expõe que para a tribo buriate da Sibéria Meridional, o xamã é considerado poeta, isto é, líder espiritual que tem o poder de carregar a tradição oral da tribo - tradição esta obtida através do transe no qual o poeta|xamã descobre não só a linguagem falada, como também a linguagem do trovão e do vento. Ao poeta buriate, portanto, é legado carregar a memória da tribo, sendo que é para esse poeta que, nessa tribo, a poesia mimetiza o mistério em sua morte simbólica e renascimento através do xamanismo. 
desloca o viés científico para um ponto de vista artístico-inventivo sobre a criação da espécie humana numa espécie própria de antropogênese.

Por meio de um texto de variedade ensaística - de fundo ficcional e inventivo - Flávio de Carvalho problematiza certos automatismos conceituais que regeram o diapasão modernista, como alma e corpo cartesianamente distintos e diametralmente antagônicos. Tendo em vista que, para Flávio, a arte moderna deveria ser capaz de penetrar nas regiões mais profundas da percepção psíquica - de modo que a perspectiva artística deixasse definitivamente de ser somente um ritual para ser um problema de sensibilidade maior -, por meio de uma espécie de escrita teórica selvagem (ao mesmo tempo, racional e lírica) o artista sugestiona pensar a arte como um ofício capaz de imaginar novas possibilidades de existência para o homem no mundo moderno.

De forma análoga a uma prática de crítica cultural etnográfica de viés surrealista, as pesquisas experimentais que compõem A origem animal de deus propõem lidar com um plano ampliado pelo qual a arte seja concebida como instância investigadora e perscrutadora de traços psíquicos selvagens remanescentes à civilização ocidental. A ideia não seria negar o processo civilizatório, mas sim rever suas premissas. Por meio de tal acepção, F.C. sonda instâncias primitivas basilares do pensamento humano que teriam sido reprimidas pelo processo civilizatório: o medo, o sexo e a invenção da alma, o sonho e a fome.

Na inventiva classificatória presente na etnografia particular flaviana, a fome tem papel rudimentar e inaugural. Para F.C., até mesmo a moral seria proveniente da fome, sendo a fome ancestral característica do modus vivendi do homem primitivo. A consciência perceptiva da fome seria a mola existencial capaz de multiplicar o acesso às camadas mais profundas da mente humana. Seria no estômago - local da percepção mais imediata do homem, de defesa do indivíduo pela satisfação do apetite - onde o berço originário dos primeiros deuses do mundo teria sido gerado.

Para a teoria especulativa presente em $A$ origem animal de deus, o aparelho digestivo humano, o berço de todo sentimento religioso é a base de todo ritual religioso formada pelo apetite de uma fome filosófica, existencial e ancestral. A ingestão de alimentos ligar-se-ia às emoções primordiais do homem, favorecendo, assim, sua sobrevivência e dotando-o de um sentimento ritualístico (no início sem dogmas) pelo qual, no decorrer dos tempos, seria celebrada as grandes ocasiões religiosas com alimentos animais. Para o pensamento selvagem do homem ancestral, o animal inferior seria o seu igual e mesmo seu superior, não somente em força bruta, como também em inteligência, uma vez que, entre os povos primitivos, tanto os homens como os animais possuíam o dom da magia. Como conjecturado 
ao longo da linha argumentativa de $A$ origem animal de deus, o sentimento religioso humano teria se desenvolvido juntamente com o sentimento transposto de sua alimentação.

Por meio de tal perspectiva, a base da sensibilidade religiosa humana ligar-se-ia a uma experiência extásica do pensamento primitivo frente à natureza - experiência que seria responsável por despertar um mundo interior no homem através de uma fantasmagoria ritual própria. Como argumentado por Flávio de Carvalho, além do culto aos deuses animais, um homem antropófago que adiciona ao seu valor o valor da vítima poderia ser encontrado em tempos míticos através de uma antropofagia ritualística de traços telúricos, ligada a uma forma de canibalismo orgiástico pela qual, em idades remotas, a divindade era retalhada pelos fiéis e devorada como síntese da fome e do medo ${ }^{15}$.

Por ser, em um passado remoto, a antropofagia uma prática comum entre a espécie humana, a origem animal de deus presente nos primeiros seres do mundo proveria de um desejo humano de licantropia (pressuposta transformação do homem em animais encontrada em povos selváticos), sendo o consequente desejo de comer carne crua indicação de uma época ancestral na qual o homem se considerava igual ao animal e devorava o seu semelhante para se alimentar, em ato de alusiva alteridade:

Comer a carne está ligado à alegria, à violência e à tristeza rápida e catastrófica de um começo de coisas; a antropofagia é uma bela e cativante manifestação da inocência do homem. Tanto antropofagia como carnivorismo são mostras da grande amizade que uma vez existiu entre homem e animal, da encantadora promiscuidade que fazia do homem o companheiro de peito do animal. A caça ao animal e ao homem era uma expressão dessa amizade, uma generosa brincadeira [...]. As crenças animísticas de toda parte mostram que um homem que mastiga a carne de um outro ou de um animal, adquire os característicos desse outro ou desse animal. (CARVALHo, 2005, p. 96-97).

Como aludido em A origem animal de deus, as primeiras fabulações poéticas da humanidade permaneceriam presentes nas narrativas míticas e nas rezas

15 "A prática da antropofagia ritualística era a síntese da Fome e do Medo, era o Sim mais imediato dos sentimentos humanos que surgia como defesa ecológica: o homem cedia às imposições mais imediatas. O homem de hoje apenas começa a dizer Não, ele ainda é antropófago, ainda come o seu deus retalhado e bebe o seu sangue, não é ainda um analista e ainda acalanta os vestígios de sua angústia animal, os vestígios que se encontram em toda a parte e na voraz vertigem de todo o seu passado" (CARvalho, 1973, p. 58). 
primevas, havendo, por conseguinte, um marcado caráter teatral religioso que, responsável por lidar com certa liturgia da fome, precisaria ser reiteradamente reencenado ao longo da história do homem. Para Flávio de Carvalho, teria sido a partir de sua capacidade de lidar com a fome que o homem primitivo, depois de adquirir domínio sobre algumas de suas deficiências de memória - após controlar os processos de amnésia, hiperamnésia e paramnésia -, teria conseguido praticar os primeiros rituais da humanidade ${ }^{16}$.

O primeiro teatro humano teria sido concebido pelo bailado mímico do homem primitivo, ao representar as estações e o surto de vida que o libertaria de uma fome inicial. Conjugado com tendências mágicas telúricas, o processo de identificação e de memorização do mundo exterior teria conduzido tal homem primitivo a uma fantasmagoria originária, a formar uma hipersensibilidade geradora de sobrevivência: o primeiro teatro da humanidade; a origem animal de deus:

A origem animal de Deus pode ser localizada há pelo menos um milhão de anos atrás. O sr. Ralph Solecke da Universidade de Columbia, em investigações arqueológicas no Líbano, descobriu restos antigos de veado que, ao que parece, recebeu enterro ritualístico em meados do Paleolítico. Se bem que a primeira linguagem surgida com o antropoide no Terciário colocaria a possibilidade de um deus-animal a período muito anterior ao Paleolítico e aos hominídeos e hominianos. [...] O primitivo não se distinguia muito do resto do mundo animal. A origem animal de Deus, encontrada nos resíduos da História, aponta para um teísmo que evolui à medida que a percepção do homem se desenvolve, em certo momento, culminando com um deus reproduzindo a própria imagem do homem. No início é o animal mais forte, considerado pelo homem, o seu superior, que é reverenciado como deus e continua, assim, mesmo quando o homem o considera o seu igual. (CARVAlHO, 1973, p. 71-72).

Indicado ao longo da linha argumentativa de $A$ origem animal de deus, seria de um passado totêmico/primitivo que certas reminiscências provindas do fundo do inconsciente humano seriam emanadas, ligadas à própria morfologia animal de

16 Como distingue Flávio de Carvalho, o fenômeno de repetição pela hiperamnésia seria peculiar ao teatro e à sua prática, sendo pelo seu uso extensivo que o ator se sobreporia à amnésia. À medida que o homem comum e o ator sobrepõem a amnésia através da hiperamnésia (adquirida pela repetição sistemática de seus atos), mais próximos estariam do poeta e do visionário, sendo, então, capazes de ascender à paramnésia: "O irrealismo fantasmagórico da paramnésia não pertence ao ator, ao bailarino ou ao bailado sacerdotal mas sim ao poeta e ao visionário que penetra com a sua introspecção em mundos recuados dentro do inconsciente" (CARVALHO, 1973, p. 23). 
antepassados ancestrais. Segundo Flávio de Carvalho (CARvalHo, 1973, p. 45-73), o vínculo entre o homem e seus deuses teria constituído um estado psíquico fundamental no desenvolvimento e na expansão da humanidade ao longo do tempo, sendo possível encontrar em materiais lendários de épocas remotas deuses com cabeças de animais e corpos humanos. Com o decurso da história, passando por representações totêmicas de homens nômades e seminômades, o homem sedentário da civilização teria se tornado proeminentemente racista e desenvolvido um sentimento de ascendência frente ao resto do mundo animal, cultivando, assim, um deus antropomórfico e mitigando a origem animal de deus.

Entrementes, segundo leitura presente em $A$ origem animal de deus, precisamente por permanecer no inconsciente humano ao longo dos tempos, o deus-animal dos povos primitivos seria uma espécie ancestral de possibilidade perspectivista de transubstanciação entre homens e bichos. Sendo, além de lendária e anterior às primeiras hierarquias, vestígio de sobrevivência em idade moderna do culto primitivo do animal, a dúplice transmutação de animais em homens e homens em animais presente no pensamento selvagem seria, para Carvalho, uma indicação de que o homem primevo considerava, inevitavelmente, o animal como o seu igual, ou, até mesmo, seu superior ${ }^{17}$.

Por ser a origem dos deuses animal, o deus-animal mítico, de quando em quando, ressurgiria na história humana através de manifestações do selvagem. Como exemplo, o ato cristão de comer o deus no ritual da missa católica e de beber seu sangue seria uma reminiscência antropofágica indicativa do processo licantrópico de nivelamento do homem ao animal em tempos remotos.

Segundo F.C., o sentimento animista primário humano seria a fome; fome tanto fisiológica quanto cósmica, sendo que seu princípio de ação pressuporia não só uma imaginação livremente criadora, como também difusora de procedimentos fecundos capazes de metabolizar o potencial etnográfico do mundo, uma vez que sua energia combativa do real agiria através de traços inconscientes de uma vida anímica ativa e ativável pela pesquisa da etnografia da história, uma vez que o homem seria o animal que para sobreviver teria criado a cultura. De modo a ampliar tal perspectiva, é possível ler a abordagem da antropofagia por

17 Tendo como ponto de apoio a origem animal de deus, segundo ponto de vista flaviano, a inconstância da alma selvagem poderia ser simbolizada pelo galo - animal totêmico de caráter volátil: "Com frequência os povos do mundo concedem os seus próprios atributos psicológicos aos animais. $\mathrm{O}$ cão torna-se um símbolo de fidelidade, a pomba simboliza a simplicidade e às vezes a paz, a raposa representa a astúcia, o leão é o valor, o galo a inconstância” (CARVALHO, 1973, p. 46). 
parte de Flávio de Carvalho a partir de uma base de conceituação da fome como um sistema de pensamento e de ação.

Diferente de Oswald de Andrade, que não chegou a conhecer in loco tribos praticantes da antropofagia, Flávio de Carvalho estabeleceu contato com índios antropófagos (waimiris e xirianãs) em expedição pela Amazônia durante $1958{ }^{18}$ Inclusive, foi a partir de tal viagem que teria começado a ser escrito o livro $A$ origem animal de deus, publicado postumamente em 1973.

Para F.C., a realidade indica ser, acima de tudo, um efeito mental; a mente humana é seu lócus de experimento. Em sua invulgar investigação da vida emotiva e anímica ao longo da história humana se reúnem elementos religiosos, filosóficos, telúricos e sexuais. Não por acaso, em A origem animal de deus, o inconsciente é aludido como o local de depósito dos desejos inacabados humanos pertencentes à própria história da espécie.

Ao transferir para o milenar patrimônio emotivo de deus uma origem animal de base etnográfica suficientemente densa, a escrita teórica de $A$ origem animal de deus busca relativizar a fundamentação basilar antropomorfa da divindade cristã, uma vez que, em contrapartida à um deus antropomorfo, os povos primitivos teriam criado deuses à imagem de seus antepassados animais vertebrados. Somente após a conquista dos detalhes do apetite, o homem do começo teria estado apto a dar início aos rituais de culto dos ciclos de vida, morte e ressurreição da vegetação e da vida animal.

A partir da identificação entre objetos divinizáveis e os alimentos necessários à sobrevivência humana, a origem animal de deus seria verificável por meio da etnografia da história num período de antropogênese - época primeva e primordial marcada pela igualdade relacional entre o homem com o mundo animal, sendo possível encontrar homens-animais na etnografia dos povos "pré-históricos" ou "sem história". Em vista disso, o primacial dos pontos nevrálgicos da visão de mundo de Flávio de Carvalho aponta se centrar numa dimensão baseada na fome in perpetuum, transportada às suas raízes psíquicas ancestrais:

18 Na mesma expedição de 1958, ao longo do alto do rio Negro amazônico, Flávio de Carvalho instituiu o primeiro contato de homens brancos com a tribo desconhecida dos xirianã, escrevendo, posteriormente, a obra abordada aqui neste ensaio: A origem animal de deus. Por sua vez, em 1952, Flávio de Carvalho já havia realizado sua primeira viagem à Amazônia, pelo Rio Araguaia, a bordo de uma comitiva do projeto de documentário O Grande Desconhecido, filme idealizado pelo cineasta italiano Mário Civelli sobre o contato europeu com índios em fase de aculturação. Em tal itinerância entre os índios Carajá, após participar de um ritual musical de fertilidade, Flávio observou que tal cântico ameríndio "mostrava profundas sutilezas de diferenciação entre, por exemplo, o canto ordinário, que era monotonamente repetitivo e as músicas indígenas guerreiras, que continham as grandiosas polifonias de uma ópera civilizada" (CARvalHo apud Toledo, 1994, p. 462). 
A sensação de religião é gerada na sensação de fome. A satisfação religiosa é a satisfação da fome. Adorar deuses animais e vegetais era um problema de alimentação do homem primitivo. É pela fome que o homem entra em contato com o mundo animal e vegetal que ele devora e o ato de devorar é a primeira religião do homem. A memória do apetite é estereotipada antes de qualquer outra. Apetite é religião. Motivo porque as raízes da religião são tão fortes. As rezas de todos os povos de todos os tempos se referem ao alimento. O primeiro instinto de propriedade do homem é o apetite: possuir aquilo que perpetua o indivíduo. A posse do alimento torna-se mágica e religiosa, e ritos e ações de graça deificam o alimento. [...]. As noções de Bem e de Mal são também geradas na fome. A natureza devorada que preencheu a finalidade de perpetuar o indivíduo é boa, enquanto que a natureza devorada que o aniquila é tida como má. As noções de moral surgem desse contato com essa natureza: o imoral é tudo quanto destrói a unidade do indivíduo e da espécie, e o moral é aquilo que os perpetuam. $\mathrm{O}$ ato de fé consiste na carícia bucal e intestinal. Este elementar contato e modificação de energias, pela repetição, gera a Fé e cria o apetite, isto é, a ânsia para ter Fé. Mastigando a natureza ele tem Fé e acredita nessa natureza. É pelo intestino e pelo sexo que o homem entra em contato íntimo com a natureza: devorando a natureza ele perpetua-se. O sexo assegura a continuação da espécie enquanto que o alimento assegura a continuação do indivíduo. (CARvalHo, 1973, p. 9-11).

Ao sondá-la enquanto experimento metabolizador da consciência, Flávio de Carvalho indica retirar a fome de uma perspectiva miserabilista para depositá-la em um registro existencial ligado ao desenvolvimento da espécie humana como objeto de investigação teórico-cientifica. Pelo seu caráter inacabado e em imanência de insatisfação, pela sua capacidade relacional e por seu poder de sugestão, a fome simbolizaria o conflito produtivo das primeiras associações entre o sujeito e o mundo; sendo o elemento primevo a colocar o homem em contato com um outro - a gerar relações diretas de alteridade com o mundo.

Tendo isso em vista, além de não pretender atingir um valor social redentor através da meditação sobre a fome, as hipóteses de Flávio não oferecem nenhuma exortação política pela face miserabilista da miséria. Por meio de sua ensaística teórica, tratar-se-ia, antes, de estabelecer uma concepção existencial da fome enquanto atividade catalisadora de tensões e estados alterados de uma consciência etnográfica/filosófica humana permeável à antropogênese. Como especulado em A origem animal de deus, certa dimensão onírica teria sido necessária ao homem 
ancestral, tendo sua predominância dominado o seu princípio de desenvolvimento espiritual ${ }^{19}$.

Por atribuir importância primordial ao sonho, os homens ancestrais, assim como os ameríndios do Gran Chaco, não distinguiam o sonho da realidade. Espalhados pelas nuvens de uma primeira sensibilidade, as imagens oníricas abundariam no homem do início - a que Flávio se refere como o homem nômade; o "homem do Sim [de William James]" (Carvalho, 1973, p. 66) - em contato com um fundo mental ultrassensório:

As imagens oníricas que representaram desejos telúricos, espalhados nas nuvens da primeira sensibilidade do homem, a quimera de sua primeira volúpia, eram vencidas pela necessidade de memorizar acontecimentos a fim de sobreviver. A memória e a memorização se tornaram mecanismos de sobrevivência. O ritmo se sobrepunha ao balbucio melódico das nuvens do desejo. Ao bailado circular e ondulante do corpo e das imagens, surge como substituto o monotonal no som e no movimento. O mundo paramnésico sem sentido e sem direção, sem dúvida um mundo onírico caracteristicamente inconsciente, era substituído pela realidade imediata com sua primeira constante: a fome. [...] O ser embriagado pelo álcool, pela religião ou por tóxicos, é receptivo, abandona o mundo exterior; não oferecendo resistência, aceita as imposições desse mundo. Esse mundo receptivo, o homem do Sim, não é um analista, ele alarga o seu mundo e sintetiza, enquanto o homem do Não é um frio analista e assim fazendo encurta e diminui o seu mundo. O Sim provém da anestesia dos sentidos, relacionados ao mundo exterior provocando uma depressão e uma ação paralisante dos órgãos que acionam nesse mundo: embaraços na língua, na marcha e nos movimentos. O homem do Sim entra em estado de sonho, ele naufraga no inconsciente abraçando a quimera das profundezas do seu ser. As fronteiras cotidianas são abandonadas para a imensidão do misterioso. (CARVALHO, 1973, p. 25-51; grifos colocados).

Para Flávio de Carvalho, o mundo moderno caminharia invariavelmente para o totemismo - numa direção de concretização totêmica da igualdade entre o homem e seus deuses de origem animal. O primeiro culto humano - o culto do caçador (homem nômade, em movimento) - teria já incorporado o animal perigoso ao seu rito em forma de totem. Por meio de tal perspectiva, não seria a especialização do

19 "Coube a um messias perdido no passado, um ser alucinado, a invenção da alma" (CARVALHO, 1973, p. 61). 
homem moderno que conseguiria minimizar e abafar a imensidão do desconhecido; uma constante de todos os tempos da humanidade. Tendo isso em vista, para F.C., o artista moderno deveria ser capaz de reunir em sua produção uma relação híbrida entre mito e realidade, através de uma via crítica de pensamentos potencialmente selvagens - criativamente desorganizadores e restauradores de uma natureza processual não atrelada à ideia de progresso técnico como elemento norteador.

Segundo o ponto de vista de Flávio, ainda que por vezes ocultáveis, resíduos primitivistas encontrar-se-iam inevitavelmente presentes na arte moderna. Por isso, na teoria ideativa presente em $A$ origem animal de deus, o homem primitivo menciona compor uma entidade agressiva e destemida, dotada de um élan vital de efervescência anímica, útil para a revitalização da esfera artística moderna. Segundo ponto de vista flaviano, uma plasticidade primitiva e não domesticável do pensamento selvagem deveria ser recuperada de modo que o artista modernista conseguisse aplicar suas energias combativas em relações enferrujadas pela rotina e pelo hábito. Ao não distinguir percepção e realidade, o pensamento analógico primitivo aproximaria realidades opostas sem anulá-las em alguma síntese facilitadora. Em vista disso, segundo perspectiva flaviana, o homem primitivo já nasceria artístico.

No momento em que renega seus velhos companheiros de pasto e classifica como secundária qualquer relação subjetiva com a natureza, o homem moderno realizaria, segundo Flávio, um ato de desconsideração consciente, cuja manifestação seria proveniente de uma censura formadora de tabu - tabu esse que precisaria ser totemizado no homem moderno através da exploração de reminiscências ancestrais psíquicas passíveis de serem encontradas num inconsciente arquetípico da espécie.

Através de uma etnografia ensaística particularmente integrada à linguagem da criação artística, Flávio de Carvalho realiza em parte de $A$ origem animal de deus uma espécie de inventário poético da mente humana através da investigação de sentidos originários e primevos presentes na modernidade em reminiscências animistas do inconsciente ancestral da espécie. Em tal cenário crítico, ao longo do livro supracitado, a argumentação flaviana postula que a invenção de deus seria, em si, um subproduto das necessidades anímicas e cerebrais do homem primitivo.

Como ressalta F.C. (CARVAlHo, 1973, p. 18), tendo a própria ideia de culto religioso surgido com o alimento animal, o fato de deuses da vegetação - como Dionísio, Deméter, Adônis, Attis e Osíris - se apresentarem também em formas animais seria uma evidência de que, para o homem ancestral, o culto dos deuses animais teria antecedido o culto dos deuses vegetais. Por proporcionarem os primeiros 
alimentos à espécie humana, os deuses animais seriam anteriores aos deuses vegetais e, por conseguinte, aos deuses antropomórficos. Por sua vez, ao cultuar um ser diametralmente diverso como divindade, o homem primitivo buscaria inconscientemente fontes de potência remissivas a uma época de equivalência entre o homem e o animal.

Como especulado em $A$ origem animal de deus, o deus antropomórfico seria um produto do homem e estaria ligado à técnica e à domesticação da natureza. Da incapacidade humana de absorver o desconhecido é que teria surgido o monoteísmo e a noção de um deus como receptáculo de tudo o que é misterioso e inexplicável:

A descoberta de sua imagem pelo homem, o efeito de espelho, forma os fundamentos de escolha da moral e do Bem e do Mal. O Bem é aquilo que engrandece a imagem do gênero humano local enquanto que o Mal é aquilo que a destrói. É este o motivo pelo qual o teísmo no seu início exige que Deus tenha atributos capazes de manter relações pessoais com o gênero humano. A evolução do teísmo se assemelha se identificando à própria evolução do homem: o teísmo é um gráfico da origem animal do homem, um gráfico que atribui a origem de Deus a um animal inferior. (CARVALHo, 1973, p. 75).

Assim, ao mesmo tempo em que questiona e contextualiza o antropomorfismo de deus, Flávio indica sua origem animal no homem ancestral através de exemplos de divindades arcaicas canibais que foram domesticadas ao longo da história da humanidade. De modo paralelo a uma visão de mundo primitiva e etnográfica, a teorética de $A$ origem animal de deus é marcada pelo sentimento totêmico de igualdade entre homens e animais, uma vez que, como indicado no livro em questão, seriam encontrados no despertar da história da humanidade animais cultivados como deuses. De modo relacionável, a produção teórica presente em $A$ origem animal de deus incita retirar a inferioridade animista do animal perante o homem. Como argumenta F.C., assim como o selvagem concede alma aos vegetais e aos animais, para o pensamento selvagem, a invenção alma não dependeria da racionalidade: "mesmo porque o homem do início até hoje não é um animal totalmente racional" (CARVALHO, 2010, p. 211).

Postulada e argumentada ao longo de $A$ origem animal de deus, a origem animal da concepção divina seria proveniente de um período em que o homem primitivo cultuava os animais totêmicos como, além de uma forma de expansão da alma, uma reminiscência dos tempos míticos em que os elos mais profundos ainda não haviam se rompido entre homem e animal. A elaboração do sentimento 
religioso humano teria surgido em um importante período de miscigenação das espécies, tendo como exemplo os dióscuros que teriam sido produzidos pela hibridização de homens e animais em luta.

Através de uma linguagem simultaneamente ensaística e ficcional, a produção textual de amplitude especulativa e verve etnográfica presente em $A$ origem animal de deus sugere abordar a criação artística num plano inconsciente de correspondência anímica cuja potencialidade seria ainda reminiscente na modernidade:

O devaneio maravilhoso do homem aparece sempre na literatura e na arte, e é por esse motivo que devemos considerar a arte sob todos os seus aspectos para melhor compreender o homem a vir. [...]. Os anseios do homem flutuam entre as forças fundamentais da sua origem e o cansaço e a estagnação de um fim de ciclo. Uma vez que o homem alcançou o fim de um ciclo, ou ele procura a sua plasticidade primitiva ou perece. [....] A arte prevê aquilo que o homem social fará. A arte é um gráfico da própria conduta do homem, é um gráfico dos acontecimentos sociais e prevê o cansaço do homem e as suas necessidades de mudança. (CARVAlHo, 2015, p. 165-167).

Para Flávio de Carvalho, enquanto inventor de mundos novos, seria necessário ao artista moderno desenvolver uma visão extensa e intensa das coisas e uma vida interior suficientemente densa capaz de abranger um poder de sugestão permanente por se completar. A reminiscência do não acabado lhe é fundamental na prática artística. Não por acaso, numa de suas últimas entrevistas, em 1970, Flávio declarou ser, para ele, a arte uma sinfonia positivamente por acabar. ${ }^{20}$ Por sua vez, em Os ossos do mundo, F.C. propôs: "O pintor verdadeiramente inteligente jamais termina a sua obra, e a grande beleza da pintura automática, super-realista, está no ineditismo sempre novo que apresenta" (CARvalHo, 2005, p. 71).

De modo paralelo a tal proposição de uma obra artística em permanente estado de abertura, nas especulações teóricas presentes em A origem animal de deus, o raciocínio empírico e o pensamento analítico indicam aproximar a invenção artística da investigação científica, gerando uma espécie de ciência ensaística - a

20 "Para mim, a arte é como uma sinfonia inacabada. Quando pinto um quadro, penso que poderia prosseguir na obra sem nunca terminar. Creio que a criação nunca é finita, não há obra de arte completa ou acabada. Nós devemos, portanto, permanecer sempre em trânsito, atentos a toda mobilização de pensamento ou criação. Eu paro de pintar um quadro quando julgo que atingi um certo equilíbrio, mas isso é um julgamento provisório, subjetivo. Cada artista deve incorporar sempre: não só elementos técnicos ou materiais, mas principalmente novas filosofias" (CARVALHO, 2015, p. 227-228). 
conjugar intelecto e experimentação. Tendo em vista tal concepção de uma ciência ensaística (e, em certo ponto, artística), a escrita etnográfica de $A$ origem animal de deus pode ser lida como um modo próprio de crítica cultural antimemorialista e antipassadista diante de qualquer realidade dada como irrevogável ${ }^{21}$.

De modo a sondar a realidade mais psíquica e reflexivamente do que visual e contemplativamente, a escrita teórica de Flávio de Carvalho parece antever na arte uma função lúdica de desenvolvimento das faculdades psíquicas do homem. A pintura surrealista (ou super-realista) o auxilia a singrar pelos territórios desconhecidos de suas searas. Interessa-lhe no surrealismo, sobretudo, uma encenação da gênese do pensamento humano e a valorização de um mundo inorgânico para o qual os surrealistas lançam luz. É caro a ele em arte os perturbadores da ordem estética. Ao deslocar a arte do lugar de passatempo da alta civilização moderna, Flávio de Carvalho busca lhe reinjetar vida, preterindo a contemplação em prol de uma reflexão ativadora de novas sensibilidades plásticas. Por se tratar de um tipo de produção artística que busca reavivar a memória ancestral da espécie, a poética surrealista desempenha, para Flávio, um protagonismo fundamental no mundo moderno de reencantamento das forças poéticas sugestivas das potencialidades mentais e anímicas humanas.

Tendo isso em vista, para Flávio, o saber transversal surrealista incita mais do que um estilo estético: um modo de ler a realidade e o mundo. Por considerá-lo, como, acima de tudo, um processo de conhecimento e de aproximação do misterioso, a teoria ensaística de Flávio de Carvalho identifica no surrealismo uma encenação da gênese do pensamento humano ao longo da história da civilização e de seus festins de relações em indissolúvel tensionamento. Arquétipo de um desejo do inconsciente primitivo e ancestral da espécie, o surrealismo teria surgido na modernidade através de uma necessidade expressionista humana de maior comunicação entre os sujeitos e seus fenômenos psíquicos:

A pintura não-naturalista, e particularmente as pinturas expressionistas, super-realistas e abstracionistas, são exemplos berrantes da existência de uma 'atmosfera' não mensurável pela física moderna. Essas pinturas possuem as recordações mais dramáticas da alma do homem; estão completamente fora da ideia

21 Sobre a ideia de uma não-memória proposta como procedimento artístico por Flávio de Carvalho, J. Toledo comenta que tal leitmotiv flaviano funcionaria como uma "poderosa arma psicológica de autodefesa com a qual se afastava prudentemente de qualquer eventual relação 'passadista' que lembrasse o Tempo ou anti-higiênicos vínculos com o passado" (Toledo, 1994, p. 482). Por sua vez, em 1973 (ano de seu falecimento), Flávio afirmou: "Resolvi readquirir o saudável hábito de cultivar a não-memória” (CARVAlHo apud Toledo, p. 712). 
cronológica de tempo, as formas pintadas são animistas, e possuem tão grande carga de sugestibilidade, que vivem e pensam como tudo mais. São formas que pertencem à morfologia dos resíduos mais remotos do mundo, dos resíduos de mundos perdidos, daqueles que só o fundo da alma e uma intensa elaboração poética podem recordar. (CARVALHO, 2005, p. 44).

Por sua vez, como ressaltou Tristan Tzara em entrevista a Flávio de Carvalho de 1935, o papel do artista (poeta e inventor da linguagem) no mundo moderno consistiria em, pelos meios que lhe são acessíveis, desagregar ideias e embaralhar a lógica vigente, de modo a incluir em seu método composicional certa base selvagem de orientação através de uma linguagem comparativa analógica metafórica:

O papel do poeta consiste, pelos meios da linguagem que o caracterizam, em demonstrar que uma certa ductibilidade do laisser alller voluptuoso da matéria linguística torna possível a transformação da linguagem. [...]. O estudo da etnografia, em si, só apresenta interesse quando esclarece um modo de pensamento outro que não aquele que empregamos... assim tornando possível no futuro aquilo que já foi feito no passado com relação às atitudes do pensamento humano. [...]. Por exemplo, as descobertas do século XVIII, de Copérnico, Newton... Os enciclopedistas deixaram traços não somente pelos conceitos de designação, mas, sobretudo, intrinsecamente à língua, sintaticamente, nos modos de pensamento. (TZARa apud CARVALHo, 2010, p. 84).

Tal observação supracitada de Tzara parece ter sido incorporada, complexificada e ampliada à formulação escritural etnográfica de Os ossos do mundo e $A$ origem animal de deus. Como problematizado neste ensaio, na escrita etnográfica de Flávio de Carvalho, o artista e o cientista sugerem dialogar sem maiores impedimentos, de modo que suas elucubrações especulativas de amplitudes teóricas aludem fazer do artista um etnógrafo da mente (ou psicoetnógrafo), cuja eclética atividade se combina à de um pensador da vasta cultura da humanidade.

\section{REFERÊNCIAS BIBLIOGRÁFICAS}

Antelo, Raúl. Maria com Marcel: Duchamp nos trópicos. Belo Horizonte: Ed. UFMG, 2010. Argan, Giulio Carlo. Arte e Crítica d’Arte. Lisboa: Editorial Estampa. 1995.

Carvalho, Flavio de Rezende. Os ossos do mundo. (1 ${ }^{\mathrm{a}}$ edição). Rio de Janeiro: Editora Ariel, 1936.

A origem animal de deus. São Paulo: Difusão Europeia do Livro, 1973. 
. Os ossos do mundo. ( $2^{\mathrm{a}}$ edição). São Paulo: Editora Antiqua, 2005.

. Flávio de Carvalho. São Paulo: MAM-SP, 2010.

. Flávio de Carvalho. Rio de Janeiro: Azougue Editorial, 2015.

ClIfFord, James. "Introduction: Partial Truths" In: Clifford \& MARCUS (Org.). Writing culture: The poetics and politics of ethnography. Berkley and Los Angeles: University of California Press, 1986.

The predicament of culture; twentieth-century ethnography, literature and art. Massachusetts: Harvard University Press, 1988.

. A experiência etnográfica: Antropologia e Literatura no século XX. Rio de Janeiro: Editora UFRJ, 1998.

DAHER, Luiz Carlos. Flávio de Carvalho: arquitetura e expressionismo. São Paulo: Projeto, 1982.

ELíade, Mircea. Oxamanismo e as técnicas arcaicas do êxtase. São Paulo, Martins Fontes, 2002.

Freyre, Gilberto. "Prefácio” In: Carvalho, Flavio de Rezende, 2005 (obra citada).

LeIRIS, Michel. A África fantasma. São Paulo: Cosac Naify, 2007.

LeITe, Rui Moreira. Flávio de Carvalho: o artista total. São Paulo: Editora Senac SP, 2008. TolEdo, José. Flávio de Carvalho: o comedor de emoções. São Paulo: Brasiliense; Campinas, SP: Ed. UNICAMP, 1994.

WAGner, Roy. A invenção da cultura. São Paulo: Cosac Naify, 2012. 